\title{
ANALISIS PENGARUH KARAKTERISTIK INDIVIDU DAN KARAKTERISTIK PEKERJAAN TERHADAP KEPUASAN KERJA SERTA DAMPAKNYA PADA KOMITMEN ORGANISASI
}

(Studi Pada Karyawan Outsourcing Kantor Komisi Independen Pemilihan (KIP) Kota Lhokseumawe)

\author{
Ayu Anora, Marbawi, Mariyudi
}

PPIM Universitas Malikussaleh, Lhokseumawe

\begin{abstract}
The purpose of this study is to examine the analysis of the effect of individual characteristics and job characteristics on job satisfaction and its impact on organizational commitment. This study uses individual characteristics and job characteristics as independent variables, this study also uses job satisfaction as intervening variable and organizational commitment as a dependent variable. The study was conducted at the Office of Independent Election Commission of Lhokseumawe City. In this study used simple random sampling technique that is by giving questionnaires to the sample respondents. This sample amounted to 125 respondents. Data analysis techniques in this study using SEM (Structural Equation Modeling) analysis which is operated through WarpPLS 3.0 program. The results of this study indicate that individual characteristics and job characteristics have a significant effect on job satisfaction and increase organizational commitment. On the other hand the effect of job satisfaction on organizational commitment is significant. Job satisfaction mediates the relationship between individual characteristics and job characteristics to organizational commitment is positively significant.
\end{abstract}

Keywords: Individual Characteristics, Job Characteristics, Job Satisfaction, Organizational Commitment

\section{PENDAHULUAN}

Dengan terus meningkatnya persaingan diberbagai bidang membuat proses pengelolaan dan pemeliharaan manajemen mendapatkan perhatian khusus dari berbagai elemen yang ada dalam organisasi untuk menciptakan sistem manajerial yang tangguh sehingga mampu mengikuti perkembangan saat ini. Dengan demikian sumber daya manusia dalam hal ini yaitu pegawai atau karyawan pada lembaga organisasi.

Komitmen organisasi adalah dorongan dari dalam individu untuk berbuat sesuatu agar dapat menunjang keberhasilan organisasi sesuai dengan tujuan dan lebih mengutamakan kepentingan organisasi dibandingkan dengan kepentingan sendiri (Weiner dalam Coryanata, 2004). Komitmen organisasi diperlukan sebagai salah satu indikator kinerja karyawan. Karyawan dengan komitmen yang tinggi dapat diharapkan akan memperlihatkan kinerja yang optimal.

Bagi industri swasta maupun instansi publik, penelitian tentang kepuasan kerja dilakukan dalam rangka usaha meningkatkan produksi dan efisiensi melalui perbaikan sikap dan perilaku karyawan. Kepuasan kerja karyawan sering menyangkut tentang emosi atau kondisi perasaan terhadap suatu pekerjaan. Menurut Handoko (2000) kepuasan kerja adalah suatu keadaan emosional 
yang menyenangkan atau tidak menyenangkan dengan mana para pegawai memandang pekerjaan mereka. Dalam hal ini, keadaan emosi pegawai menjadi ukuran terhadap kepuasan kerjanya.

Di dalam organisasi, karyawan akan menunjukkan sikap yang mencerminkan bagaimana persepsinya terhadap perusahaan. Sikap adalah keteraturan perasaan dan pikiran seseorang dan kecenderungan bertindak terhadap aspek lingkungannya. Dalam perilaku organisasi, ada tiga sikap yang berkaitan dengan pekerjaan yaitu keterlibatan kerja, kepuasan kerja, dan komitmen organisasional (Robbins \& Judge, 2008). Keterlibatan kerja merupakan derajat dimana orang dikenal dari pekerjaannya, berpartisipasi aktif didalamnya, dan menganggap prestasinya penting untuk harga diri (Robbins, 2003).

Menurut Job Characteristics Model yang dikembangkan oleh Hackman dan Oldham (1975) dalam Chang, dkk. (2006), karakeristik pekerjaan mempengaruhi kinerja karyawan, kepuasan kerja, dan perilaku pengunduran diri. Berdasarkan model ini, pekerjaan yang sifatnya lebih menantang dan perubahan-perubahan yang memberi otonomi yang lebih besar kepada karyawan akan memberikan inspirasi kepada karyawan, meningkatkan kepuasan karyawan, dan mengurangi turn-over atau pengunduran diri karyawan.

Pada tingkatan individu, karakteristik dari masing-masing individu (personal) yang meliputi: cirri pribadi atau biografis seperti: usia, jenis kelamin, status perkawinan, cirri kepribadian, nilai dan sikap dan tingkat-tingkat kemampuan dasar akan mempengaruhi perilaku mereka ditempat kerja (Robbins, 2003). Dampak dari karakteristik individu yang banyak menjadi perhatian bagi pengamat dan peneliti organisasi adalah pada kepuasan kerja karyawan dan komitmen karyawan terhadap organisasi (LokdanCrawford;2001, 2003), Chonko (1986), WU (2001), Bashaw dan Grant (1994), Ellicson (2002),Ting (1997). Berbagai hasil penelitian tersebut menunjukkan bahwa karakteristik individu mempunyai pengaruh yang signifikan baik terhadap kepuasan kerja maupun komitmen organisasi.

Adapun fenomena-fenomena yang terjadi yakni berkenaan dengan kepuasan kerja dan komitmen organisasi terhadap karyawan outsourcing pada Kantor Komisi Independen Pemilihan (KIP) Kota Lhokseumawe, penulis melihat dan mendapat informasi bahwa loyalitas karyawan dan tingkat kemajuan terhadap organisasi menurun. Kantor Komisi Independen Pemilihan (KIP) Kota Lhokseumawe berusaha memberikan yang terbaik bagi karyawan outsourcing agar kepuasan kerja para karyawan outsourcing lebih efektif dan efesien sehingga berdampak positif bagi organisasi.

Melalui pengamatan peneliti sementara karyawan outsourcing kurang menunjukkan sikap yang baik dalam bekerja atau kinerja yang kurang optimal, hal ini dapat dilihat dari adanya karyawan outsourcing yang tidak menghadiri bimbingan teknis (bimtek) atau simulasi yang diberikan, selain itu keterampilan dalam menyelesaikan tugas yang dimiliki tidak terlalu signifikansi, sehingga mempengaruhi efektifitas kinerja.

Beberapa penelitian sebelumnya yang telah mencoba menguji kebenaran dari teori dan pandangan yang telah dikemukakan di atas tentang faktor-faktor penting yang mempengaruhi kepuasan kerja dan komitmen organisasi. Dengan pengalaman, seseorang mempelajari kebutuhannya sekaligus mengevaluasi mengenai balas jasa organisasi kepada dirinya serta keterlibatannya dalam organisasi. Melalui proses belajar inilah pengalaman akan memberikan pengaruh terhadap kepusan kerja (Robbins, 2003). Kesesuaian antara nilai individu, pekerjaan dan apa yang diterima dari organisasi akan 
mengarah pada kepuasan kerja. Selain itu, nilai-nilai sosial yang tinggi akan mengarah kepada kepuasan kerja yang tinggi (Meglino \& Ravlin,1998; Rokeach,1973 dalam Robbins2003).

Upaya untuk meningkatkan kepuasan kerja dan komitmen organisasi karyawan outsourcing saat ini Komisi Independen Pemilihan (KIP) Kota Lhokseumaweberupaya menyesuaikan dengan faktorfaktor yang berpengaruh terhadap komitmen organisasi dan kepuasan kerja karyawan outsourcing tersebut diantaranya jumlahpekerjaan, kualitas pekerjaan, ketetapan waktu, kehadiran, lingkungan kerja, dan kemampuan kerja sama.

Realita secara umum bahwa karakteristik individu serta karakteristik pekerjaan yang penulis amati pada kantor Komisi Independen Pemilihan (KIP) Kota Lhokseumawe yang ditunjukkan oleh sebagian karyawan outsourcing dapat dikelola dengan baik. Namun demikian, adapun fenomena tersebut belum tentu sejalan dengan hasil penelitian yang akan dilakukan nantinya. Berdasarkan latar belakang tersebut, maka penulis tertarik untuk melakukan penelitian dengan judul "Analisis Pengaruh Karakteristik Individu Dan Karakteristik PekerjaanTerhadap Kepuasan Kerja Serta Dampaknya Pada Komitmen Organisasi Outsourcing (Studi Pada Kantor Komisi Independen Pemilihan (KIP) Kota Lhokseumawe)".

\section{METODE}

Objek dalam penelitian ini adalah karyawan Outsourcing Kantor Komisi Independen Pemilihan (KIP) Kota Lhokseumawe Jalan Antara No. 4c Kampung Jawa Baru, Kecamatam Banda Sakti, Kota Lhokseumawe.

Populasi dalam penelitian ini adalah karyawan Outsourcing kantor Komisi Independen Pemilihan (KIP) Kota Lhokseumawe yang berjumlah 216, yang terdiri dari 4 (empat) kecamatan dimana kecamatan Banda Sakti berjumah 57 karyawan Outsourcing, Muara Dua berjumlah 54 karyawan Outsourcing, Blang Mangat 69 karyawan Outsourcing, Muara Satu 36 karyawan Outsourcing.

Untuk penentuan jumlah sampel dalam penelitian ini juga mempertimbangkan model penelitian yang digunakan. Penelitian ini menggunakan teknik Probability Sampling yaitu teknik pengambilan sampel yang memberikan peluang yang sama bagi setiap unsur (anggota) populasi untuk dipilih menjadi anggota sampel (Sugiyono, 2014). Teknik Sampling yang digunakan yaitu dengan metode Proportionate Stratified Random Sampling. Rumus Slovin adalah sebuah rumus atau formula untuk menghitung jumlah sampel minimal apabila perilaku dari sebuah populasi tidak diketahui secara pasti. Rumus ini pertama kali diperkenalkan oleh Slovin pada tahun 1960. Rumus slovin ini biasa digunakan dalam penelitian survey dimana biasanya jumlah sampel besar sekali, sehingga diperlukan sebuah formula untuk mendapatkan sampel yang sedikit tetapi dapat mewakili keseluruhan populasi. Rumus Slovin dapat dilihat berdasarkan notasi sebagai berikut:

$$
\mathrm{n}=\mathrm{N} /\left(1+\left(\mathrm{N} \mathrm{x} \mathrm{e}^{2}\right)\right)
$$

Dari notasi diatas, $\mathrm{n}$ adalah jumlah sampel minimal, nilai $\mathrm{N}$ adalah populasi sedangkan nilai $\mathrm{e}$ adalah error margin. Berangkat dari ide perihal margin error inilah mungkin sang pencipta dari rumus ini memberikan kesempatan kepada para peneliti untuk menetapkan besar sampel minimal berdasarkan tingkat kesalahan atau margin of error. 
Sehingga: $\mathrm{n}=1000 /\left(1+\left(216 \times 0,06^{2}\right)\right)$

$$
\begin{aligned}
& \mathrm{n}=216 /(1+(216 \times 0,0036)) \\
& \mathrm{n}=216 / 1,7776=121
\end{aligned}
$$

Ada beberapa pedoman penentuan besarnya sample size untuk SEM PLS yang digunakan dalam penelitian ini disesuaikan dengan model analisis WarpPLS dimana sample dimungkinkan dibawah 100 dan diatas 100 atau besar kecil samplel tidak jadi masalah dalam analisis WarpPLS. Adapun jumlah sampel dalam model penelitian ini adalah sebanyak 121 sampel sebagai nilai minimal, namun demikian untuk menghindari tingkat kesalahan atau margin of error maka sampel digenapkan menjadi 125 sampel.

\section{HASIL}

\section{Deskriptif Jawaban Responden}

a. Variabel karakteristik individu

Deskriptif statistik jawaban responden variabel karakteristik individu adalah deskripsi mengenai jawaban responden tentang item-item pernyataan berdasarkan indikator karakteristik individu. Berdasarkan data dalam Tabel 5.2 dapat dijelaskan bahwa nilai minimum adalah 2, nilai maksimum adalah 5 dan nilai rata-rata (mean) jawaban responden tentang karakteristik individu sebesar 3,8601. Nilai standar deviasi sebesar 0,93105 dan nilai tersebut tidak melebihi dua kali nilai mean. Hal tersebut menandakan bahwa sebaran data sudah baik. Apabila dihubungkan dengan skala yang ditentukan dalam penelitian ini yaitu: (1) sangat tidak setuju, (2) tidak setuju, (3) netral, (4) setuju, (5) sangat setuju, maka katagori jawaban responden secara rata-rata berada pada skala (3) mendekati 4 atau pada kondisi netral mendekati setuju dan artinya secara umum responden berpendapat setuju terhadap penyataan dalam kuisioner mengenai karakteristik individu.

\section{b. Variabel karakteristik pekerjaan}

Deskriptif statistik jawaban responden variabel karakteristik pekerjaan adalah deskripsi mengenai jawaban responden tentang item-item pernyataan variabel karakteristik pekerjaan. Berdasarkan data dalam Tabel 5.3 dapat dijelaskan bahwa nilai minimum adalah 2, nilai maksimum adalah 5 dan nilai rata-rata mean jawaban responden tentang karakteristik pekerjaan sebesar 3,7496. Nilai standar deviasi atau simpangan baku sebesar 0,94751 hal tersebut menunjukkan bahwa secara keseluruhan nilai standar deviasi tidak ada yang melebihi dua kali nilai mean. Hal tersebut menandakan bahwa sebaran data sudah sangat baik. Apabila dihubungkan dengan skala yang ditentukan dalam penelitian ini yaitu : (1) sangat tidak setuju, (2) tidak setuju, (3) netral, (4) setuju, (5) sangat setuju, maka katagori jawaban responden secara rata-rata berada pada skala (3) mendekati 4 atau pada kondisi netral mendekati setuju dan artinya secara umum responden berpendapat setuju terhadap penyataan dalam kuisioner mengenai karakteristik pekerjaan. 
c. Variabel kepuasan kerja

Deskriptif statistik jawaban responden tentang variabel kepuasan kerja adalah deskripsi mengenai jawaban responden tentang item-item pernyataan berdasarkan indikator variabel kepuasan kerja. Berdasarkan data dalam Tabel 5.4 dapat dijelaskan bahwa nilai minimum adalah 1 , nilai maksimum adalah 5 dan nilai rata-rata mean jawaban responden tentang variabel kepuasan kerja sebesar 3,5552. Nilai standar deviasi atau simpangan baku sebesar 0,93515. Hal tersebut menunjukkan bahwa secara keseluruhan nilai standar deviasi tidak ada yang melebihi dua kali nilai mean. Hal tersebut menandakan bahwa sebaran data sudah baik. Apabila dihubungkan dengan skala yang ditentukan dalam penelitian ini yaitu : (1) sangat tidak setuju, (2) tidak setuju, (3 netral, (4) setuju, (5) sangat setuju, maka katagori jawaban responden secara rata-rata berada pada skala 3 atau pada kondisi netral artinya responden memberi pandangan yang baik pada penyataan dalam kuisioner mengenai variabel kepuasan kerja.

d. Variabel komitmen organisasi

\begin{tabular}{|c|c|c|c|c|}
\hline \multicolumn{3}{|c|}{ Path Model } & Coefficients & $\mathbf{P}$ \\
\hline $\begin{array}{c}\text { Karakteristik Individu } \\
\text { (KI) }\end{array}$ & $\rightarrow$ & $\begin{array}{c}\text { Kepuasan Kerja } \\
(\mathrm{KK})\end{array}$ & 0,342 & 0,018 \\
\hline $\begin{array}{c}\text { Karakteristik Pekerjaan } \\
\qquad(\mathrm{KP})\end{array}$ & $\rightarrow$ & $\begin{array}{c}\text { Kepuasan Kerja } \\
(\mathrm{KK})\end{array}$ & 0,357 & 0,008 \\
\hline $\begin{array}{l}\text { Karakteristik Individu } \\
\text { (KI) }\end{array}$ & $\rightarrow$ & $\begin{array}{c}\text { Komitmen } \\
\text { Organisasi (KO) }\end{array}$ & 0,235 & 0,003 \\
\hline $\begin{array}{c}\text { Karakteristik Pekerjaan } \\
\text { (KP) }\end{array}$ & $\rightarrow$ & $\begin{array}{c}\text { Komitmen } \\
\text { Organisasi (KO) }\end{array}$ & 0,157 & 0,043 \\
\hline Kepuasan Kerja (KK) & & $\begin{array}{c}\text { Komitmen } \\
\text { Organisasi (KO) }\end{array}$ & 0,511 & $<0.001$ \\
\hline
\end{tabular}

\begin{tabular}{cccc}
\hline Variabel & Mean & Std. Deviation & Kategori \\
\hline Karakteristik Individu & 3,8601 & 0,93105 & Baik \\
Karakteristik Pekerjaan & 3,7496 & 0,94751 & Baik \\
Kepuasan Kerja & 3,5552 & 0,93515 & Baik \\
Komitmen Organisasi & 3,4539 & 0,91358 & Baik \\
\hline Rata-rata & 3,6547 & 0,93182 & Baik \\
\hline
\end{tabular}

Deskriptif statistik jawaban responden variabel komitmen organisasi adalah deskripsi jawaban responden tentang item-item pertanyaan komitmen organisasi. Berdasarkan data dalam Tabel 5.5 dapat dijelaskan bahwa nilai minimum adalah 1, nilai maksimum adalah 5 dan nilai rata-rata mean jawaban responden tentang komitmen organisasi sebesar 3,4539, Nilai standar deviasi atau simpangan baku sebesar 0,91358 hal tersebut menunjukkan bahwa secara keseluruhan nilai deviasi standar tidak ada yang melebihi dua kali nilai mean. Hal tersebut menandakan bahwa sebaran data sudah baik. Apabila 
dihubungkan dengan skala yang ditentukan dalam penelitian ini yaitu : (1) sangat tidak setuju, (2) tidak setuju, (3) netral, (4) setuju, (5) sangat setuju, maka katagori jawaban responden secara rata-rata berada pada skala 3 atau pada jawaban netral artinya responden memberi jawaban netral pada penyataan dalam kuisioner mengenai komitmen organisasi.

\section{PEMBAHASAN}

Berdasarkan analisis factor konfirmatori pada keempat variabel penelitian (karakteristik pekerjaan, karakteristik individu, kepuasan kerja dan komitmen organisasi) diperoleh hasil indicator dari variabel karakteristik individu dan kepuasan kerja ada yang perlu dihilangkan/didrop dari analisis. Hal ini disebabkan karena nilai loading factor yang dihasilkan $<0,40$. Oleh karena itu indikator KI7 dari variabel karakteristik individu, dan KK6 dari variabel kepuasan kerja tidak ditampilkan.

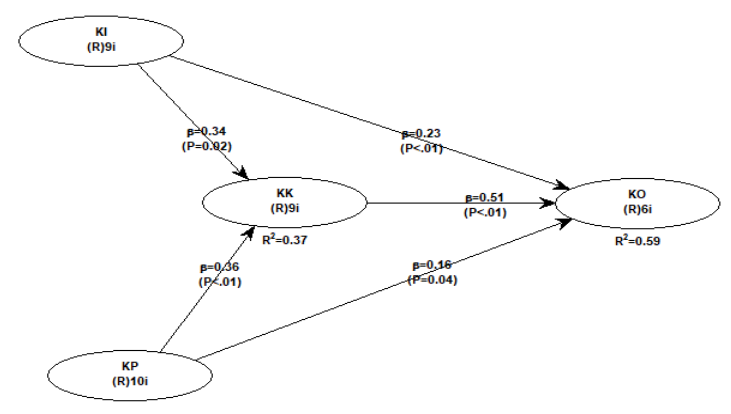

Gambar 5.8 Model Struktural dan Hasil Perhitungan WarpPLS

Tabel 5.13 Pengaruh Variabel Eksogen terhadap Variabel Endogen

\begin{tabular}{|c|c|c|c|c|}
\hline & KI & KP & KK & KO \\
\hline R-Squared & & & 0.366 & 0.587 \\
\hline Compositereliab. & 0.934 & 0.917 & 0.927 & 0.936 \\
\hline $\begin{array}{c}\text { Cronbach's } \\
\text { Alpha }\end{array}$ & 0.920 & 0.899 & 0.911 & 0.918 \\
\hline Avg. var.extrac. & 0.613 & 0.525 & 0.584 & 0.710 \\
\hline Full Collin. VIF & 1.648 & 1.591 & 2.210 & 2.420 \\
\hline Q-squared & & & 0.368 & 0.582 \\
\hline
\end{tabular}


Tabel 5.6 Rangkuman Deskriptif Jawaban Responden

\begin{tabular}{|c|c|c|c|}
\hline Variabel & Mean & $\begin{array}{c}\text { Std. } \\
\text { Deviation }\end{array}$ & Kategori \\
\hline Karakteristik Individu & 3,8601 & 0,93105 & Baik \\
\hline Karakteristik Pekerjasn & 3,7496 & 0,94751 & Baik \\
\hline Kepuasan Kerja & 3,5552 & 0,93515 & Baik \\
\hline Komitmen Organisasi & 3,4539 & 0,91358 & Baik \\
\hline Rata-rata & 3,6547 & 0,93182 & Baik \\
\hline
\end{tabular}

Tabel 5.10

Hasil Output Latent Variable Coefficients

\begin{tabular}{|c|c|c|c|c|}
\hline \multicolumn{3}{|c|}{ Path Model } & Coefficients & $\mathbf{P}$ \\
\hline $\begin{array}{l}\text { Karakteristik } \\
\text { Individu (KI) }\end{array}$ & $\rightarrow$ & $\begin{array}{l}\text { Kepuasan } \\
\text { Kerja (KK) }\end{array}$ & 0,342 & 0,018 \\
\hline $\begin{array}{l}\text { Karakteristik } \\
\text { Pekerjaan (KP) }\end{array}$ & $\rightarrow$ & $\begin{array}{l}\text { Kepuasan } \\
\text { Kerja (KK) }\end{array}$ & 0,357 & 0,008 \\
\hline $\begin{array}{l}\text { Karaktenstik } \\
\text { Individu (KI) }\end{array}$ & $\rightarrow$ & $\begin{array}{l}\text { Komitmen } \\
\text { Organisasi } \\
\text { (KO) }\end{array}$ & 0,235 & 0,003 \\
\hline $\begin{array}{l}\text { Karaktenstik } \\
\text { Pekerjaan (KP) }\end{array}$ & $\rightarrow$ & $\begin{array}{l}\text { Komitmen } \\
\text { Organisasi } \\
\text { (KO) }\end{array}$ & 0,157 & 0,043 \\
\hline $\begin{array}{l}\text { Kepuasan Kerja } \\
(\mathrm{KK})\end{array}$ & & $\begin{array}{l}\text { Komitmen } \\
\text { Organisasi } \\
\text { (KO) }\end{array}$ & 0,511 & $<0.001$ \\
\hline
\end{tabular}

Tabel 5.11

\section{Hasil Output Model Fit Indices}

\begin{tabular}{|c|c|c|c|c|}
\hline Fut Indices & Indeks & p-value & Kriteria & Keterangan \\
\hline $\begin{array}{l}\text { Average Path } \\
\text { Coefficient } \\
\text { (APC) }\end{array}$ & 0,320 & $p<0,001$ & $p<0,05$ & Diterima \\
\hline $\begin{array}{c}\text { Average R- } \\
\text { squared (ARS) }\end{array}$ & 0.477 & $p<0,001$ & $p<0,05$ & Diterima \\
\hline $\begin{array}{l}\text { Average } \\
\text { Variance } \\
\text { Inflation Factor } \\
\text { (AVIF) }\end{array}$ & $\begin{array}{c}1,457 \\
\text { Good if }<5\end{array}$ & & AVIF $<5$ & Diterima \\
\hline
\end{tabular}

Hasil output di atas, menjelaskan bahwa APC memiliki indeks sebesar 0,320 dengan nilai $\mathrm{p}$ - value $<0,001$. Sedangkan ARS memiliki indeks sebesar 0,477 dengan $\mathrm{p}-$ value $<0,001$. Berdasarkan kriteria, APC sudah memenuhi kriteria karena memiliki nilai $\mathrm{p}<0,001$. Begitu pula dengan nilai $\mathrm{p}$ dari ARS yaitu $\mathrm{p}<0,001$. Nilai AVIF yang harus $<5$ sudah terpenuhi karena berdasarkan data tersebut AVIF nilainya 1,457. Dengan demikian, maka inner model dapat diterima. 
Tabel 5.12 Nilai R² Pada Variabel

\begin{tabular}{|c|c|c|c|}
\hline & $\begin{array}{l}\text { Karakteristik } \\
\text { Individu }\end{array}$ & $\begin{array}{c}\text { Karakteristik } \\
\text { pelkerjaan }\end{array}$ & $\begin{array}{c}\text { Kepuasan } \\
\text { Kerja }\end{array}$ \\
\hline \multicolumn{4}{|l|}{ Direct Effects } \\
\hline Kepuasan kerja & 0,342 & 0,357 & - \\
\hline $\begin{array}{l}\text { Komitmen } \\
\text { Organisasi }\end{array}$ & 0,235 & 0,157 & 0,511 \\
\hline \multicolumn{4}{|c|}{ Indirect Effects for Path with 2 Segments } \\
\hline $\begin{array}{l}\text { Komitmen } \\
\text { Organisasi }\end{array}$ & 0,175 & 0,182 & - \\
\hline$p$-value & 0,046 & 0,020 & - \\
\hline \multicolumn{4}{|l|}{ Total Effects } \\
\hline Kepuasan kerja & 0,342 & 0,357 & - \\
\hline $\begin{array}{l}\text { Komitmen } \\
\text { Organisasi }\end{array}$ & 0,410 & 0,339 & 0,511 \\
\hline
\end{tabular}

Menurut Chin (1998), nilai R square sebesar 0,67 (kuat), 0.33 (moderat) dan 0,19 (lemah). Tabel 5.12 menunjukkan nilai $\mathrm{R}^{2}$ atau koefisien determinasi pada kontruk endogen. Variabel kepuasan kerja (KK) memiliki nilai $\mathrm{R}^{2}$ 0,368 yang mengindikasikan bahwa sebesar 36,8\% variasi kepuasan kerja dapat dijelaskan oleh karakteristik individu (KI), dan karakteristik pekerjaan (KP). Sedangkan nilai $\mathrm{R}^{2}$ atau koefisien determinasi variabel komitmen organisasi (KO) adalah sebesar $R^{2} \quad 0,582$ yang mengindikasikan bahwa sebesar 58,2 \% variasi komitmen organisasi dapat dijelaskan oleh karakteristik individu (KI), karakteristik pekerjaan (KP), dan kepuasan kerja (KK).

Tabel 5.14

Standardized Direct, Indirect dan Total Effects

\begin{tabular}{|l|c|}
\hline \multicolumn{1}{|c|}{ Variabel Laten } & R Square \\
\hline Kepuasan Kerja & 0,368 \\
\hline Komitmen & 0,582 \\
\hline Organisasi & \\
\hline
\end{tabular}

\section{KESIMPULAN}

Karakteristik Individu, berpengaruh signifikan terhadap Kepuasan Kerja karyawan outsourcing Komisi Independen Pemilihan Kota Lhokseumawe. Karakteristik Pekerjaan, berpengaruh signifikan terhadap Kepuasan Kerja karyawan outsourcing Komisi Independen Pemilihan Kota Lhokseumawe. Karakteristik Individu, berpengaruh signifikan terhadap Komitmen Organisasi karyawan outsourcing Komisi Independen Pemilihan Kota Lhokseumawe. Karakteristik Pekerjaan, berpengaruh signifikan terhadap Komitmen Organisasi karyawan outsourcing Komisi Independen Pemilihan Kota Lhokseumawe. Kepuasan Kerja, berpengaruh signifikan terhadap Komitmen Organisasi karyawan outsourcing Komisi Independen Pemilihan Kota Lhokseumawe. Kepuasan Kerja memediasi hubungan antara Karakteristik Individu terhadap Komitmen Organisasi karyawan outsourcing Komisi Independen Pemilihan Kota Lhokseumawe, artinya Kepuasan Kerja dapat memediasi secara parsial hubungan Karakteristik Individu terhadap Komitmen Organisasi karyawan outsourcing Komisi Independen Pemilihan Kota Lhokseumawe. Kepuasan Kerja memediasi hubungan antara Karakteristik Pekerjaan terhadap Komitmen Organisasi karyawan outsourcing Komisi Independen Pemilihan Kota Lhokseumawe, artinya Kepuasan Kerja dapat memediasi secara parsial hubungan Karakteristik 
Pekerjaan terhadap Komitmen Organisasi karyawan outsourcing Komisi Independen Pemilihan Kota Lhokseumawe.

\section{SARAN}

Sesuai dengan hasil yang diperoleh dalam pengujian statistic variabel kepuasan kerja berpengaruh signifikan terhadap komitmen organisasi maka variabel kepuasan kerja perlu menjadi fokus perhatian pertama sekretariat Komisi Independen Pemilihan Kota Lhokseumawe, salah satu yang dapat meningkatkan pengaruh variabel tersebut dapat ditempuh melalui upaya menciptakan kepuasan sesuai dengan hasil deskriptif statistik yang menunjukkan nilai rata-rata paling sedikit pada pernyataan Mean KK $1(3,8943)$ dengan memberikan kesempatan untuk belajar, promosi, dan secretariat memberikan dukungan kepada karyawan outsourcing, serta kerja sama yang terus ditingkatkan antar pekerja, baik karyawan tetap maupun outsourcing.

\section{DAFTAR REFERENSI}

Aditya, Mahardika Widjana. 2010. "Determinan Faktor Penerimaan Terhadap. Internet Banking Pada Nasabah Bank Di Surabaya”. Thesis Program. Pasca Sajrana. Sekolah Tinggi Ilmu Ekonomi Surabaya. Diunduh dari ebook.library.perbanas.ac.id/7091_TESIS.pdf, diakses tanggal 20 Maret. 2014.

Al Rasyid, Harun. 2000. Dasar-dasar statistika terapan. Bandung: program pascasarjana UNPAD.

Anggraini, Aminanty Puspita. 2016. "Direct And Indirect Illocutionary Acts Found In The Alchemist" Novel By Paulo Coelho". Jurnal Humanis, Volume V. No. 1.http://id.portalgaruda.org/?ref=author\&mod=profile\&id=228614. Diakses pada hari selasa 21 Maret 2017.

A.F Stoner, James dan Edward Freeman (eds) (2004), Manajemen Jilid I, terj. Alexander Sindoro, Jakarta: PT Prahallindo.

Agung Panudju, 2003, "Pengaruh Kompensasi dan Karakteristik Pekerjaan terhadap Kepuasan Kerja Karyawan unit PT.X Palembang”.

Ahmadi, Candra., Dadang Hermawan. 2013. E-Busiess \& E-Commerce. Yogyakarta: Andi.

Arief Subyantoro (2009). Karakteristik Individu, Karakteristik Pekerjaan,. Karakteristik Organisasi Dan Kepuasan Yang dimediasi Oleh Motivasi Kerja,. Jurnal Aplikasi Manajemen, 11(1), 11-19.

As'ad, (2001), Psikologi Industri, edisi ke-4.cetakan ke-6.Yogyakarta: Liberty. 
A.S. Munandar. 2001. Psikologi Industri dan Organisasi. Depok. Penerbit. Universitas. Indonesia (UIPress).

Baron, R. M. and Kenny, D. A. 1986. The Moderator-Mediator Variable Distinction in Social Psychological Research: Conceptual, Strategic, and Statistical Considerations. Journal of Personality and Social Psychology, 51(6), 1173-1182.

Bangun, Wilson. 2012. "Manajemen Sumber Daya Manusia". Jakarta: Erlangga.

Cooper, Donal R. dan Emory, William, 1999. Metode Penelitian Bisnis, alih bahasa Widyono Soecipto dan Uka Wikarya, Jilid 11, Jakarta: Erlangga.

David, Fred R.. 2005. Strategic Management : Concepts and Cases, (10th ed.).. USA: Prentice Hall, Inc.

David, Fred R.. 2011. Strategic Management : Concepts and Cases, (10th ed.).. USA: Prentice Hall, Inc.

Edy Sutrisno, 2014. Manajemen Sumber Daya Manusia. Cetak Ke Enam.Pranada Media Group, Jakarta.

Ferdinand, Augusty. (2014). Metode Penelitian Manajemen, Semarang, Badan. Penerbit Universitas Diponegoro.

Ghozali, Imam. 2014. Structural Equation Modeling, Metode Alternatif dengan. Partial Least Square (PLS). Edisi 4. Semarang : Badan Penerbit Universitas. Diponegoro.

Ghozali, Imam. 2013. Aplikasi Analisis Multivariate dengan Program IBM SPSS. 21 Update PLS Regresi. Semarang: Badan Penerbit Universitas. Diponegoro.

Gibson, James, L., 2000, Organisasi, Perilaku, Struktur dan Proses, Edisi ke-5. Cetakan ke-3. Jakarta: Penerbit Erlangga.

Gibson, James L., John M. Ivancevich dan James H. Donnelly, Jr. (1996). Organisasi, Perilaku, Struktur, Proses, (Alih Bahasa Nunuk Adiarni (2006)), Penerbit Binarupa Aksara, Jakarta.

Hackman, J.R., \& Oldham, G.R. (1980). Work Redesign. Reading, MA: Addison. Wesley Publishing Company.

Handoko, T H. 2004. Manajemen Personalia dan Sumberdaya Manusia. BPFE,. Yogyakarta.

Henry Simamora. 2004. Manajemen Sumber Daya Manusia. Edisi Ketiga. Yogyakarta: STIE YKPN.

Kreitnerand Kinicki. 2009. Perilaku Organisasi.Edisi5. Jakarta: SalembaEmpat. 
Luthans,Fred. 2011.Organizational Behaviour.Sevent Edition . New York : McGraw-HillCompanies,Inc.

Luthans, Fred. 2011. Organizational Behavior: An Evidence-Based approach. New York: The McGrowHill Companies, Inc.

Marbawi. 2017. Pengaruh Karakteristik Individu, Budaya Organisasi, dan Kepemimpinan Transformasional terhadap Kepuasan Kerja dan Kinerja Karyawan Pada PT. Bank Aceh.

Mathis, R.L. \& J.H. Jackson. 2006. Human Resource Management: Manajemen Sumber. Daya Manusia. Terjemahan Dian Angelia. Jakarta: Salemba Empat.

Allen, NJ., Meyer PJ. And Smith CA. 1993. "Commitment to Organizations and Occupations : Extension and Test of a Three-Component Conceptualization”, Journal of Applied Psychology, Vol. 78, No. 4.

McShane, Steven L., Mara Olekalns, Tony Travaglione, Organizational Behavior Emerging Knowledge. Global insight 4 edition. Asia: McGraw Hill, 2013.

Moekijat, Drs, 2003, Manajemen Sumber Daya Manusia, Bandung: Pionir Jaya.

Mowday, R.T., Steers, R.M., \& Porter, L. (1979). The measurement of organizational commitment. Journal of Vocational Behaviour, 14, 224-. 247.

R. Soeprapto, 1986, Undang-Undang Pokok Agraria Dalam Praktek , Jakarta, C.V. Mitra Sari.RichardL.Hughes,RobertC.Ginnett,andGordon J.Curphy.2012.Leadership, Enhancingthe LessonsofExperience,AlihBahasa: PutriIzzati.Jakarta: SalembaHumanika.

Rivai,VeithzaldanEllaSagala.2006.ManajemenSumberDayaManusiauntukPerusahaan: $\quad$ Dari Teori kePraktik.Jakarta: PT RajaGrafindo Persada.

Rivai, Veitzal, dan Deddy Mulyadi. 2011. Kepemimpinan dan PerilakuOrganisasi.Jakarta: Rajawali Pers.

Robbins, Stephen P. 2001.OrganizationBehaviour. 7th Edition. PrenticeHall, Englewood Clifts, N.J.

Robbins, Stephen P. 2003.OrganizationBehaviour. Jakarta: Gramedia.

Robbins,StephenP.\&A.Judge,Timothy.(2001).Perilakuorganisasi.Edisi12. Salemba empat. Jakarta 12160. 
Robbins, Stephen P. \&A. Judge, Timothy (2011). Organizational behavior. Fourteenth Edition.Pearson education. New Jersey07458. 77-89*.Robbins, Stephen P \& Judge, Timothy A. 2013. Organizational Behavior Edition. 15. New Jersey: Pearson Education.

Randal S. Schuler dan Susan E. Jackson, 1997: 228, Manajemen Sumber Daya. Manusia, Buku Satu, Edisi Indonesia. PT Salemba Empat, Jakarta.

Sekaran, Uma. 2007. Metodologi Penelitian untuk Bisnis.Edisi 4.Buku 2. Jakarta: Salemba Empat.

Siahaan, Marihot P. 2016. Pajak Daerah dan Retribusi Daerah. Edisi Revisi. Jakarta: Rajawali Pers.

Sobel, M. E. (1982). Asymptotic confidence intervals for indirect effect in structural equation models. In S. Leinhardt (Ed.), Sociological Methodology 1982 (pp. 290-312).Washington DC: American Sociological Association.

SondangP.Siagian,2013,“Manajemen SumberDayaManusia”, Jakarta: BumiAksara

Sopiah. 2008. Perilaku Organisasi, Yogyakarta: Andi.

Sugiyono (2015). Metode Penelitian Kombinasi (Mix Methods). Bandung: Alfabeta.

Sugiyono.2014.MetodePenelitianPendidikanPendekatanKuantitatif,Kualitatif $\quad$ Dan $\quad R \& D$. Bandung: Alfabeta.

Supriyanto, Budi 2009. Manajemen Tata Ruang. Tanggerang: Media Briliant.

Sutrisno. (2009), Manajemen Keuangan Teori, Konsep dan Aplikasi, Edisi Pertama, Cetakan. Ketujuh, Penerbit Ekonisia, Yogyakarta.

Stone and Kroll,. 1991. Volleyball Predominan Sytem. Energy.. dari http//: Physicaleducation's posteur.com. Di akses pada 28 mei. 2011.

Thoha, Miftah, 2010. Kepemimpinan Dalam Manajemen, Jakarta: Rajawali Pers.

Thoha, Miftah, 2010. Perilaku Organisasi Konsep Dasar dan Aplikasinya, Jakarta: PT. Raja Grafindo Persada. 